九州大学学術情報リポジトリ

Kyushu University Institutional Repository

\title{
Demographic Parameters of Long-term Laboratory Strains of the Brown Planthopper, Nilaparvata lugens Stål, (Homoptera: Delphacidae) on Resistance Genes, bph20(t) and Bph21(t) in Rice
}

Myint, Khin Khin Marlar

Institute of Biological Control, Division of Insect Natural Enemies, Department of Applied Genetics and Pest Management, Graduate school of Bioresource and Bioenvironmental Sciences, Kyushu University

Matsumura, Masaya

Research Team for Insect Pest and Nematode Management, National Agricultural Research Center for Kyushu Okinawa Region

Takagi, Masami

Institute of Biological Control, Division of Insect Natural Enemies, Department of Applied Genetics and Pest Management, Graduate school of Bioresource and Bioenvironmental Sciences, Kyushu University

Yasui, Hideshi

Plant Breeding Laboratory, Division of Genetics and Plant Breeding, Department of Applied Genetics and Pest Management, Graduate school of Bioresource and Bioenvironmental Sciences, Kyushu University

https://doi.org/10.5109/14053

出版情報：九州大学大学院農学研究院紀要. 54 (1)，pp.159-164，2009-02-27. Faculty of Agriculture, Kyushu University

バージョン：

権利関係 : 


\title{
Demographic Parameters of Long-term Laboratory Strains of the Brown Planthopper, Nilaparvata lugens Stål, (Homoptera: Delphacidae) on Resistance Genes, bph20(t) and Bph21(t) in Rice
}

\author{
Khin Khin Marlar MYINT ${ }^{1}$, Masaya MATSUMURA ${ }^{2}$, \\ Masami TAKAGI ${ }^{1}$ and Hideshi YASUI ${ }^{3} *$
}

\author{
Plant Breeding Laboratory, Division of Genetics and Plant Breeding, Department of \\ Applied Genetics and Pest Management, Graduate school of Bioresource and \\ Bioenvironmental Sciences, Kyushu University, \\ Fukuoka 812-8581, Japan \\ (Received November 14, 2008 and accepted December 5, 2008)
}

\begin{abstract}
The demographic parameters of four laboratory strains of the brown planthopper (BPH), Nilaparvata lugens (Stål) collected in Japan between 1966 and 2005, were evaluated using near-isogenic lines (NILs) and pyramided line (PYL) of rice carrying recently identified genes, bph2O(t) and Bph21 (t) conferring resistance to BPH. Six traits: adult survivorship, development of female abdomen, nymph survivorship, nymphal developmental period, adult body weight, and oviposition were examined. Based on the adult survivorship and development of female abdomen, the BPH strains of Hatano-66 and Chikugo-89 were avirulent to bph20(t)-NIL and Bph21(t)-NIL as well as their PYL carrying both bph2O(t) and Bph21(t). On the other hand, the BPH strains of Isahaya-99 and Nishigoshi-05 were virulent to bph20(t)-NIL and Bph21(t)-NIL but still avirulent to their PYL. Four other demographic parameters of the avirulent strains of BPH showed low nymph survivorship, prolonged nymphal developmental period, light body weight of adults and small number of eggs laid on the resistant lines to $\mathrm{BPH}$. These results suggest that a resistance mechanism such as feeding inhibition caused by the two major genes resistance to $\mathrm{BPH}$, similarly affect both on nymphal and adult stages. The PYL with both $b p h 20(\mathrm{t})$ and $B p h 21(\mathrm{t})$ had an epistatic effect of resistance to the BPH strains migrated into Japan since 1999
\end{abstract}

Keywords: Nilaparvata lugens (Stål), virulence, rice, near-isogenic lines (NILs), pyramided line (PYL)

\section{INTRODUCTION}

The brown planthopper (BPH), Nilaparvata lugens (Stål), is one of the most destructive pests of rice throughout the rice-growing tropical, subtropical and temperate areas in Asia. BPH causes direct damage to rice plants by sucking the plant sap. Heavy infestations cause complete drying and plant death, a condition known as "hopperburn". BPH also causes crop damage by transmitting serious virus diseases, such as grassy stunt (Rivera et al., 1966) and ragged stunt (Ling et al., 1978). Resistant varieties were released to farmers for commercial cultivation, but the situation become alarming when their resistance became ineffective because of the apparent selection for a virulent biotype of the pest (Khush, 1979). The term biotype refers to the populations of $N$. lugens which differs in their ability to feed on and destroy varieties with a specific major gene for

\footnotetext{
Institute of Biological Control, Division of Insect Natural Enemies, Department of Applied Genetics and Pest Management, Graduate school of Bioresource and Bioenvironmental Sciences, Kyushu University

Research Team for Insect Pest and Nematode Management, National Agricultural Research Center for Kyushu Okinawa Region, Kumamoto 861-1192, Japan

${ }^{3}$ Plant Breeding Laboratory, Division of Genetics and Plant Breeding, Department of Applied Genetics and Pest Management, Graduate school of Bioresource and Bioenvironmental Sciences, Kyushu University

* Corresponding author (E-mail: hyasui@agr.kyushu-u.ac.jp)
}

resistance (Diehl and Bush, 1984). To date, the BPH resistance conferred by major genes seem not to be durable; $B p h 1$ and bph 2 are already broken down by biotype 2 and 3 in South East Asia (Pathak and Heinrichs, 1982). In East Asia, monitoring of field populations revealed that the BPH migrating to Japan showed increased virulence against the resistance gene $B p h 1$ around 1988-1990 (Sogawa, 1992). Virulence against bph2 in $\mathrm{BPH}$ populations in East Asia was first identified in Japan in 1997 (Tanaka, 1999; Tanaka and Matsumura, 2000), and the virulence has remained at a high level through 1999 in East Asian countries. Recently we revealed that the two major genes resistance to $\mathrm{BPH}$, bph2O(t) and Bph21 (t) were mapped in a highly resistant variety ADR52 (Myint et al., 2009b, Submitted). The near-isogenic lines (NILs) and a pyramided line (PYL) for BPH resistance were developed by marker-assisted selection using SSR markers near resistance genes, $\operatorname{bph} 20(\mathrm{t})$ and $B p h 21(\mathrm{t})$. We also revealed that the long-term mass rearing of BPH strains in the laboratory did not change their virulence status (Myint et al., 2009a). Thus, these strains will be useful for the analysis of genes for resistance against BPH. In the present study, we examined the virulence and demographic parameters of laboratory BPH strains collected in Japan between 1966 and 2005 on recently identified resistance genes, $b p h 20(\mathrm{t})$ and Bph21 (t) and their PYL. 


\section{MATERIALS AND METHODS}

\section{NILs and their PYL of rice}

The two major genes conferring resistance to $\mathrm{BPH}$, bph20(t) and Bph21(t), derived from an Indian rice variety ADR52 were recently mapped on rice chromosomes 6 and 12, respectively (Myint et al., 2009b, Submitted). The two NILs and a PYL for BPH resistance were developed by marker-assisted selection using SSR markers near the genes resistance to $\mathrm{BPH}$, bph2O(t) and Bph21 (t) (Fig. 1).

(1) bph20(t)-NIL $[b p h 20(\mathrm{t}) / b p h 20(\mathrm{t})]$, $\operatorname{Bph21}(\mathrm{t})-\mathrm{NIL}[B p h 21(\mathrm{t}) / \operatorname{Bph} 21(\mathrm{t})]$ and $(3) \operatorname{bph} 20(\mathrm{t})$, Bph21(t)-PYL [bph20(t)/bph20(t)Bph21 (t)/Bph21(t)] were selected in the $\mathrm{BC}_{4} \mathrm{~F}_{2}$ generation. The bph20(t)NIL and Bph21(t)-NIL carried homozygous alleles of bph20(t) and Bph21(t) with the genetic background of T65, respectively. The bph20(t), Bph21(t)-PYL had homozygous alleles of both of bph20(t) and Bph21(t) with the genetic background of T65. ADR52 and T65 were used as resistant and susceptible check, respectively.

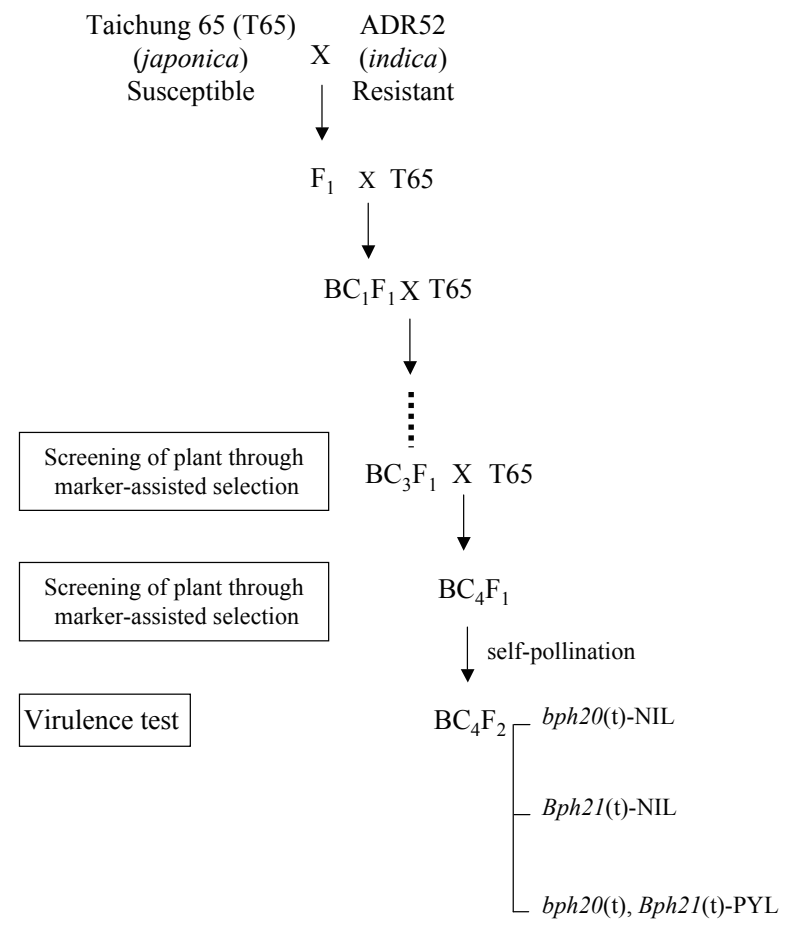

Fig. 1. Breeding scheme for development of near-isogenic lines (NILs) and pyramided line (PYL) for BPH resistance.

\section{Insect strains}

Four BPH strains were evaluated: (1) Hatano-66 strain collected from Hatano, Kanagawa Prefecture, Japan in 1966, (2) Chikugo-89 strain collected from Chikugo, Fukuoka Prefecture, Japan in 1989, (3) Isahaya-99 strain collected from Isahaya, Nagasaki Prefecture, Japan in 1999, and (4) Nishigoshi-05 strain collected from Koshi, Kumamoto Prefecture, Japan in 2005. They are maintained separately by continuously rearing on susceptible variety 'Reihou' at $25 \pm 1{ }^{\circ} \mathrm{C}$ under $16 \mathrm{~h}$ light and $8 \mathrm{~h}$ dark condition in the National Agricultural Research Center for Kyushu Okinawa Region (KONARC).

\section{Virulence test}

Seeds of the tested lines were sown individually in plastic cups $(220 \mathrm{ml})$ with soil. One-month old seedlings were trimmed to $15 \mathrm{~cm}$ height, and each trimmed plant was covered with a transparent plastic cylindrical cage $(5 \mathrm{~cm} \mathrm{D} \times 25 \mathrm{~cm} \mathrm{H})$. Five brachypterous (short-wing form) females within $24 \mathrm{~h}$ after emergence were released into the cage and the open end was covered with a nylon cloth. The number of insects that survived and the shape of their abdomens were monitored at 5 days after infestation (DAI). We classified females with heavily swollen abdomens or that survived for five days as virulent, and females that died within five days as avirulent (Tanaka and Matsumura, 2000). This system of classification is similar to that used by Tanaka (2000) for identifying virulent and avirulent females. Eight independent replicates of the experiment were performed.

Subsequently, we investigated nymph survival, developmental period and adult body weight in the Hatano-66, Isahaya-99 and Nishigoshi-05 strains. Ten newly hatched $\mathrm{BPH}$ nymphs were released to a single rice plant one month after sowing. The survived nymphs were transferred to the new plant at 9DAI and all the emerged adults were counted after 14DAI. The nymphal developmental periods were recorded and the emerged adults were kept at $-4{ }^{\circ} \mathrm{C}$ and weighed by a microbalance (Mettler Toledo, UMX-2). In the oviposition test, five brachypterous females with swollen abdomens reared on susceptible variety 'Reihou' were released to a single rice plant at one month after sowing. After $24 \mathrm{~h}$, females were removed and the plant parts above the soil were cut. The samples were kept in 70\% ethanol and dissected under a microscope. The number of eggs deposited was recorded.

\section{Statistical analysis}

Data were analyzed using ANOVA and treatment means were subjected to multiple comparisons using the Tukey-Kramer test (SAS Institute Inc., 2003). The rate of surviving insects (\%) and the proportion of females with swollen abdomens (\%) were arcsine-transformed and the number of eggs deposited was log-transformed prior to analysis.

\section{RESULTS}

\section{Adult survivorship and development of female abdomen on NILs and their PYL of rice}

Adult survival rates and development of the $\mathrm{BPH}$ female abdomen are shown in Table 1 and Table 2, respectively. High proportions of females with swollen abdomens survived on T65 within 5DAI. Small proportions of Hatano-66 and Chikugo-89 females survived on NILs (bph20(t)-NIL and Bph21(t)-NIL), PYL (bph20 (t), Bph21(t)-PYL), and ADR52 (resistant check) ranging from 0 to $20.0 \%$ and all the females that survived did not show a swollen abdomen. In contrast, high proportions of Isahaya-99 females survived on the 
Table 1. Adult survival rates (\%) of Nilaparvata lugens strains on NILs and their PYL of rice

\begin{tabular}{|c|c|c|c|c|}
\hline \multirow{2}{*}{ Line } & \multirow{2}{*}{ Resistance gene } & \multicolumn{3}{|c|}{ Nilaparvata lugens strains $\mathrm{s}^{\mathrm{a}, \mathrm{b}}$} \\
\hline & & Hatano-66 & Chikugo-89 & Isahaya-99 \\
\hline bph20(t)-NIL & $\operatorname{bph} 20(\mathrm{t})$ & $20.0 \pm 6.5 \mathrm{~b}$ & $5.0 \pm 3.3 \mathrm{~b}$ & $87.5 \pm 3.7 \mathrm{a}$ \\
\hline Bph21(t)-NIL & $\operatorname{Bph21}(\mathrm{t})$ & $2.5 \pm 2.5 \mathrm{c}$ & $2.5 \pm 2.5 \mathrm{~b}$ & $100.0 \pm 0.0 \mathrm{a}$ \\
\hline $\operatorname{bph} 20(\mathrm{t}), B p h 21(\mathrm{t})-\mathrm{PYL}$ & $\operatorname{bph} 20(\mathrm{t}), B p h 21(\mathrm{t})$ & $0.0 \pm 0.0 \mathrm{c}$ & $2.5 \pm 2.5 \mathrm{~b}$ & $20.0 \pm 3.8 \mathrm{~b}$ \\
\hline ADR52 (R. check) & bph $20(\mathrm{t}), B p h 21(\mathrm{t})$ & $0.0 \pm 0.0 \mathrm{c}$ & $2.5 \pm 2.5 \mathrm{~b}$ & $12.5 \pm 3.6 \mathrm{~b}$ \\
\hline T65 (S. check) & no resistance gene & $82.5 \pm 2.5 \mathrm{a}$ & $85.0 \pm 5.0 \mathrm{a}$ & $95.0 \pm 3.3 \mathrm{a}$ \\
\hline
\end{tabular}

${ }^{\text {a }}$ Hatano-66, Chikugo-89, Isahaya-99 strains were collected in 1966, 1989 and 1999, respectively.

${ }^{\mathrm{b}}$ Means (mean \pm S.E.) followed by the same letter are not significantly different at $P<0.01$, by the

Tukey-Kramer multiple comparison test.

Table 2. The proportion (\%) of Nilaparvata lugens females with swollen abdomen on NILs and their PYL of rice

\begin{tabular}{|c|c|c|c|c|}
\hline \multirow{2}{*}{ Line } & \multirow{2}{*}{ Resistance gene } & \multicolumn{3}{|c|}{ Nilaparvata lugens strains $\mathrm{s}^{\mathrm{a}, \mathrm{b}}$} \\
\hline & & Hatano-66 & Chikugo-89 & Isahaya-99 \\
\hline bph20(t)-NIL & bph20(t) & $0.0 \pm 0.0 \mathrm{~b}$ & $0.0 \pm 0.0 \mathrm{~b}$ & $80.0 \pm 3.8 \mathrm{a}$ \\
\hline$B p h 21(\mathrm{t})-\mathrm{NIL}$ & $B p h 21(\mathrm{t})$ & $0.0 \pm 0.0 \mathrm{~b}$ & $0.0 \pm 0.0 \mathrm{~b}$ & $80.0 \pm 5.3 \mathrm{a}$ \\
\hline bph2O(t), Bph21(t)-PYL & $\operatorname{bph} 20(\mathrm{t}), \operatorname{Bph} 21(\mathrm{t})$ & $0.0 \pm 0.0 \mathrm{~b}$ & $0.0 \pm 0.0 \mathrm{~b}$ & $0.0 \pm 0.0 \mathrm{~b}$ \\
\hline ADR52 (R. check) & $\operatorname{bph} 20(\mathrm{t}), B p h 21(\mathrm{t})$ & $0.0 \pm 0.0 \mathrm{~b}$ & $0.0 \pm 0.0 \mathrm{~b}$ & $0.0 \pm 0.0 \mathrm{~b}$ \\
\hline T65 (S. check) & no resistance gene & $80.0 \pm 3.8 \mathrm{a}$ & $83.0 \pm 5.9 \mathrm{a}$ & $90.0 \pm 3.8 \mathrm{a}$ \\
\hline
\end{tabular}

${ }^{a}$ Hatano-66, Chikugo-89, Isahaya-99 strains were collected in 1966, 1989 and 1999, respectively.

${ }^{\mathrm{b}}$ Means (mean \pm S.E.) followed by the same letter are not significantly different at $P<0.01$, by the

Tukey-Kramer multiple comparison test.

bph20(t)-NIL (87.5\%) and on Bph21(t)-NIL (100.0\%). Eighty percent of Isahaya-99 females showed swollen abdomens on the two NILs. However, adult survivorship in Isahaya-99 strain remained small on the PYL and ADR52 (20.0\% and 12.5\%, respectively), and all the surviving females did not show swollen abdomens. These results indicated that Hatano-66 and Chikugo-89 strains were avirulent to bph20(t)-NIL, Bph21(t)-NIL and their PYL. However, Isahaya-99 strain was virulent to bph20(t)-NIL, Bph21(t)-NIL but avirulent to the PYL.

\section{Nymphal survivorship, nymphal developmental period and adult body weight on NILs and their PYL of rice}

Nymphal survival rates of the $\mathrm{BPH}$ are shown in Table 3. Hatano-66 nymphs could not molt into adults on the PYL or ADR52, and small proportions of nymphs were developed to adults on the NILs (36.0\% on
bph20(t)-NIL and 31.0\% on Bph21(t)-NIL). In contrast, high proportions of Isahaya-99 and Nishigoshi-05 nymphs were molted into adults on the NILs similar to T65 (susceptible check), and ranging from 78.0 to 94.0\%. However, small proportions of those nymphs survived on the PYL as well as ADR52 ranging from 33.0 to $36.0 \%$.

Nymphal developmental period is shown in Table 4. The avirulent BPH strains on resistant lines such as the PYL and ADR52 showed prolonged developmental periods compared with virulent $\mathrm{BPH}$ strains on susceptible lines such as the bph20(t)-NIL, Bph21(t)-NIL and T65. The nymphal developmental period of Isahaya-99 strain was 20.8 days on the PYL and 22.0 days on ADR52 for males, and 20.8 days on the PYL and 24.0 days on ADR52 for females compared to 17.2 days for males and 17.9 days for females. The nymphal developmental period of Nishigoshi-05 strains were 20.5 days on the PYL and

Table 3. Nymphal survival rates (\%) of Nilaparvata lugens strains on NILs and their PYL of rice

\begin{tabular}{|c|c|c|c|c|}
\hline \multirow{2}{*}{ Line } & \multirow{2}{*}{ Resistance gene } & \multicolumn{3}{|c|}{ Nilaparvata lugens strains ${ }^{\mathrm{a}, \mathrm{b}}$} \\
\hline & & Hatano-66 & Isahaya-99 & Nishigoshi-05 \\
\hline bph2O(t)-NIL & $\operatorname{bph} 20(\mathrm{t})$ & $36.0 \pm 4.2 \mathrm{~b}$ & $88.0 \pm 4.1 \mathrm{a}$ & $94.0 \pm 2.6 \mathrm{a}$ \\
\hline $\operatorname{Bph} 21(\mathrm{t})-\mathrm{NIL}$ & $\operatorname{Bph21}(\mathrm{t})$ & $31.0 \pm 4.3 \mathrm{~b}$ & $78.0 \pm 5.9 \mathrm{a}$ & $82.0 \pm 4.1 \mathrm{a}$ \\
\hline bph20(t), Bph21(t)-PYL & $\operatorname{bph} 20(\mathrm{t}), B p h 21(\mathrm{t})$ & $0.0 \pm 0.0 \mathrm{c}$ & $36.0 \pm 4.2 \mathrm{~b}$ & $33.0 \pm 4.2 \mathrm{~b}$ \\
\hline ADR52 (R. check) & $\operatorname{bph} 20(\mathrm{t}), B p h 21(\mathrm{t})$ & $0.0 \pm 0.0 \mathrm{c}$ & $35.0 \pm 4.0 \mathrm{~b}$ & $36.0 \pm 3.3 \mathrm{~b}$ \\
\hline T65 (S. check) & no resistance gene & $83.0 \pm 3.6 \mathrm{a}$ & $77.0 \pm 4.2 \mathrm{a}$ & $83.0 \pm 3.3 \mathrm{a}$ \\
\hline
\end{tabular}

${ }^{a}$ Hatano-66, Isahaya-99, Nishigoshi-05 strains were collected in 1966, 1999 and 2005, respectively.

${ }^{\mathrm{b}}$ Means (mean \pm S.E.) followed by the same letter are not significantly different at $P<0.01$, by the

Tukey-Kramer multiple comparison test. 
Table 4. Nymphal developmental period of Nilaparvata lugens strains on NILs and their PYL of rice

\begin{tabular}{|c|c|c|c|c|c|}
\hline & \multirow{2}{*}{ Line } & \multirow{2}{*}{ Resistance gene } & \multicolumn{3}{|c|}{ Nilaparvata lugens strains ${ }^{\mathrm{a}, \mathrm{b}}$} \\
\hline & & & Hatano-66 & Isahaya-99 & Nishigoshi-05 \\
\hline \multirow[t]{5}{*}{ Male } & bph2O(t)-NIL & $\operatorname{bph} 20(\mathrm{t})$ & $19.8 \pm 0.2 \mathrm{~b}$ & $16.8 \pm 0.2 \mathrm{a}$ & $17.4 \pm 0.2 \mathrm{a}$ \\
\hline & $B p h 21(\mathrm{t})-\mathrm{NIL}$ & $B p h 21(\mathrm{t})$ & $20.6 \pm 0.4 \mathrm{~b}$ & $17.1 \pm 0.2 \mathrm{a}$ & $17.0 \pm 0.2 \mathrm{a}$ \\
\hline & $b p h 20(\mathrm{t}), B p h 21(\mathrm{t})-\mathrm{PYL}$ & $\operatorname{bph} 20(\mathrm{t}), \operatorname{Bph} 21(\mathrm{t})$ & - & $20.8 \pm 0.3 \mathrm{~b}$ & $20.5 \pm 0.2 \mathrm{~b}$ \\
\hline & ADR52 (R. check) & $\operatorname{bph} 20(\mathrm{t}), B p h 21(\mathrm{t})$ & - & $22.0 \pm 0.3 \mathrm{~b}$ & $21.7 \pm 0.5 \mathrm{~b}$ \\
\hline & T65 (S. check) & no resistance gene & $17.4 \pm 0.2 \mathrm{a}$ & $17.2 \pm 0.3 \mathrm{a}$ & $17.4 \pm 0.3 \mathrm{a}$ \\
\hline \multirow[t]{5}{*}{ Female } & bph2O(t)-NIL & $\operatorname{bph} 20(\mathrm{t})$ & $20.0 \pm 0.3 \mathrm{~b}$ & $18.0 \pm 0.3 \mathrm{a}$ & $17.5 \pm 0.2 \mathrm{a}$ \\
\hline & $\operatorname{Bph} 21(\mathrm{t})-\mathrm{NIL}$ & $B p h 21(\mathrm{t})$ & $21.2 \pm 0.6 \mathrm{~b}$ & $18.2 \pm 0.3 \mathrm{a}$ & $17.6 \pm 0.3 \mathrm{a}$ \\
\hline & $\operatorname{bph} 20(\mathrm{t}), B p h 21(\mathrm{t})-\mathrm{PYL}$ & $\operatorname{bph} 20(\mathrm{t}), B p h 21(\mathrm{t})$ & - & $20.8 \pm 0.2 \mathrm{~b}$ & $20.6 \pm 0.2 \mathrm{~b}$ \\
\hline & ADR52 (R. check) & $\operatorname{bph} 20(\mathrm{t}), B p h 21(\mathrm{t})$ & - & $24.0 \pm 0.7 \mathrm{c}$ & $21.7 \pm 0.5 \mathrm{~b}$ \\
\hline & T65 (S. check) & no resistance gene & $17.6 \pm 0.2 \mathrm{a}$ & $17.9 \pm 0.3 \mathrm{a}$ & $17.6 \pm 0.3 \mathrm{a}$ \\
\hline
\end{tabular}

${ }^{a}$ Hatano-66, Isahaya-99, Nishigoshi-05 strains were collected in 1966, 1999 and 2005, respectively.

${ }^{\mathrm{b}}$ Means (mean \pm S.E., days) followed by the same letter are not significantly different at $P<0.01$, by the Tukey-

Kramer multiple comparison test.

21.7 days on ADR52 for males, and 20.6 days on the PYL and 21.7 days on ADR52 for females compared to 17.4 days for males and 17.6 days for females on T65. Additionally, the Hatano-66 strain of the BPH on the two NILs showed somewhat prolonged developmental periods compared with virulent $\mathrm{BPH}$ on a susceptible check, T65.

Adult body weight is shown in Table 5. Isahaya-99 and Nishigoshi-05 strains showed light body weight of adults on the PYL and ADR52 compared to when on the
bph20(t)-NIL, Bph21(t)-NIL and T65 (susceptible check). In the Isahaya-99 strain, the adult body weight was $0.721 \mathrm{mg}$ on the PYL and $0.660 \mathrm{mg}$ on ADR52 for males, and $1.414 \mathrm{mg}$ on the PYL and $1.247 \mathrm{mg}$ on ADR52 for females compared to $1.379 \mathrm{mg}$ for males and $2.228 \mathrm{mg}$ for females on T65. In the Nishigoshi-05 strain, adult body weight was $0.909 \mathrm{mg}$ on the PYL and $0.631 \mathrm{mg}$ on ADR52 for males, and $1.321 \mathrm{mg}$ on the PYL and $1.553 \mathrm{mg}$ on ADR52 for females compared to $1.263 \mathrm{mg}$ for males and $2.387 \mathrm{mg}$ for females on T65.

Table 5. Adult body weight of Nilaparvata lugens strains on NILs and their PYL of rice

\begin{tabular}{|c|c|c|c|c|c|}
\hline & \multirow{2}{*}{ Line } & \multirow{2}{*}{ Resistance gene } & \multicolumn{3}{|c|}{ Nilaparvata lugens strains $\mathrm{s}^{\mathrm{a}, \mathrm{b}}$} \\
\hline & & & Hatano-66 & Isahaya-99 & Nishigoshi-05 \\
\hline \multirow[t]{5}{*}{ Male } & bph2O(t)-NIL & bph2O(t) & $0.948 \pm 0.044 \mathrm{~b}$ & $1.202 \pm 0.044 \mathrm{a}$ & $1.311 \pm 0.044 \mathrm{a}$ \\
\hline & Bph21(t)-NIL & Bph21(t) & $0.746 \pm 0.057 \mathrm{~b}$ & $1.201 \pm 0.048 \mathrm{a}$ & $1.243 \pm 0.060 \mathrm{a}$ \\
\hline & bph20(t), Bph21 (t)-PYL & $b p h 20(\mathrm{t}), B p h 21(\mathrm{t})$ & - & $0.721 \pm 0.057 \mathrm{~b}$ & $0.909 \pm 0.065 b$ \\
\hline & ADR52 (R. check) & bph20(t), Bph21(t) & _- & $0.660 \pm 0.049 \mathrm{~b}$ & $0.631 \pm 0.051 \mathrm{~b}$ \\
\hline & T65 (S. check) & no resistance gene & $1.356 \pm 0.044 \mathrm{a}$ & $1.379 \pm 0.044 \mathrm{a}$ & $1.263 \pm 0.055 \mathrm{a}$ \\
\hline \multirow[t]{5}{*}{ Female } & bph2O(t)-NIL & bph2O(t) & $1.599 \pm 0.060 \mathrm{~b}$ & $2.273 \pm 0.057 \mathrm{a}$ & $2.372 \pm 0.057 \mathrm{a}$ \\
\hline & $\operatorname{Bph} 21(\mathrm{t})-\mathrm{NIL}$ & $\operatorname{Bph21}(\mathrm{t})$ & $1.447 \pm 0.062 \mathrm{~b}$ & $2.271 \pm 0.057 \mathrm{a}$ & $2.483 \pm 0.057 \mathrm{a}$ \\
\hline & $\operatorname{bph} 20(\mathrm{t}), B p h 21(\mathrm{t})-\mathrm{PYL}$ & $\operatorname{bph} 20(\mathrm{t}), B p h 21(\mathrm{t})$ & _ & $1.414 \pm 0.062 \mathrm{~b}$ & $1.321 \pm 0.059 \mathrm{~b}$ \\
\hline & ADR52 (R. check) & bph20(t), Bph21(t) & - & $1.247 \pm 0.089 \mathrm{~b}$ & $1.553 \pm 0.070 \mathrm{~b}$ \\
\hline & T65 (S. check) & no resistance gene & $2.258 \pm 0.057 \mathrm{a}$ & $2.228 \pm 0.057 \mathrm{a}$ & $2.387 \pm 0.057 \mathrm{a}$ \\
\hline
\end{tabular}

${ }^{a}$ Hatano-66, Isahaya-99, Nishigoshi-05 strains were collected in 1966, 1999 and 2005, respectively.

${ }^{\mathrm{b}}$ Means (mean \pm S.E., mg) followed by the same letter are not significantly different at $P<0.01$, by the Tukey-Kramer multiple comparison test.

Table 6. Oviposition of Nilaparvata lugens strains on NILs and their PYL of rice

\begin{tabular}{|c|c|c|c|c|}
\hline \multirow{2}{*}{ Line } & \multirow{2}{*}{ Resistance gene } & \multicolumn{3}{|c|}{ Nilaparvata lugens strains ${ }^{a, b, c}$} \\
\hline & & Hatano-66 & Isahaya-99 & Nishigoshi-05 \\
\hline bph20(t)-NIL & bph20(t) & $31.8 \pm 2.6 \mathrm{~b}$ & $100.0 \pm 7.2 \mathrm{a}$ & $110.4 \pm 6.1 \mathrm{a}$ \\
\hline Bph21(t)-NIL & $B p h 21(\mathrm{t})$ & $25.8 \pm 3.0 \mathrm{~b}$ & $89.8 \pm 5.9 \mathrm{a}$ & $97.6 \pm 5.5 \mathrm{a}$ \\
\hline bph20(t), Bph21(t)-PYL & $\operatorname{bph} 20(\mathrm{t}), B p h 21(\mathrm{t})$ & $30.6 \pm 1.8 \mathrm{~b}$ & $33.8 \pm 2.4 \mathrm{~b}$ & $38.6 \pm 2.0 \mathrm{~b}$ \\
\hline ADR52 (R. check) & $\operatorname{bph} 20(\mathrm{t}), B p h 21(\mathrm{t})$ & $24.6 \pm 3.3 \mathrm{~b}$ & $25.4 \pm 5.5 \mathrm{~b}$ & $31.2 \pm 3.2 \mathrm{~b}$ \\
\hline T65 (S. check) & no resistance gene & $95.8 \pm 5.6 \mathrm{a}$ & $93.2 \pm 7.5 \mathrm{a}$ & $112.2 \pm 8.7 \mathrm{a}$ \\
\hline
\end{tabular}

${ }^{a}$ Hatano-66, Isahaya-99 and Nishigoshi-05 strains were collected in 1966, 1999 and 2005, respectively.

${ }^{\mathrm{b}}$ Means (mean \pm S.E.) followed by the same letter are not significantly different at $P<0.01$, by the

Tukey-Kramer multiple comparison test.

${ }^{c}$ Number of eggs (mean \pm S.E.) in $24 \mathrm{~h}$. 


\section{Oviposition of BPH on NILs and their PYL of rice}

The number of eggs oviposited by the BPH is shown in Table 6. In the Hatano-66 strain, few eggs were laid on the two NILs, their PYL and ADR52 ranging from 24.6 to 31.8 compared with 95.8 on $\mathrm{T} 65$. In the case of Isahaya-99 and Nishigoshi-05 strains, the large numbers of eggs laid on the two NILs was similar to that on the susceptible check, T65, but few eggs were laid on the PYL and ADR52 compared to T65. The Isahaya-99 strain showed 33.8 on the PYL and 25.4 on ADR52. The Nishigoshi-05 strain showed 38.6 on the PYL and 31.2 on ADR52.

\section{DISCUSSION}

On resistant rice varieties, adult survivorship is low and the female abdomen does not become swollen during the first five days of the adult stage in BPH (Tanaka, 1999). Thus, the evaluation method using adult survivorship and the development of the abdomen (swollen or not) are useful for the screening of resistant varieties and analysis of resistance genes in BPH (Tanaka, 1999; Tanaka and Matsumura, 2000; Myint et al., 2009a). In the present study, we first observed the relationship between adult survivorship and development of the female abdomen. Subsequently, other demographic parameters (nymph survivorship, nymphal developmental period, adult body weight, and oviposition) were analyzed. The results showed that the four demographic parameters of the BPH strains (Tables 3-6) had a quite similar pattern with respect to adult survivorship and the development of female abdomen (Tables 1 and 2), i.e., the BPH strains that had low adult survivorship with a low percentage of swollen abdomens showed low nymph survivorship, prolonged nymphal developmental period, light body weight of adults, and few eggs laid (Tables 1-6). These results suggest that a resistance mechanism such as feeding inhibition caused by the two major genes resistance to $\mathrm{BPH}$, similarly affect both nymphal and adult stages.

Subsequently, we compared the resistance levels of two newly developed NILs and their PYL using the longterm laboratory strains of the BPH collected from 1966 to 2005. The results demonstrated that either bph20(t)NIL or Bph21(t)-NIL was resistant to Hatano-66 and Chikugo-89 strains, but was susceptible to Isahaya-99 and Nishigoshi-05 strains (Tables 1-6). In contrast, the bph20(t), Bph21(t)-PYL was resistant to all the BPH strains. This means that Hatano-66 and Chikugo-89 strains were avirulent to bph20(t)-NIL and Bph21(t)NIL as well as their PYL, and that Isahaya-99 and Nishigoshi-05 strains were virulent to bph20(t)-NIL and Bph21(t)-NIL but were still avirulent to their PYL. In Hatano-66 strain, the two NILs and their PYL were resistant but the level of resistance was different, i.e., about 30\% nymphs survived on NILs but no nymph molted into adults on the PYL. Furthermore, all the demographic parameters of BPH were similar between the two NILs. These results suggest that the PYL had an epi- static effect on BPH. The possible causes of antibiosis to $\mathrm{BPH}$ in PYL could be one or more of the following: the insect did not feed enough to ingest appropriate quantities of required nutrients, the plant lacked nutrients vital for the insect, or the plants contained materials toxic to the pest.

The characteristics of the virulence of $\mathrm{BPH}$ to bph20(t) or Bph21(t) was different from that against the gene such as Bph1 conferring resistance to $\mathrm{BPH}$. The BPH strain, Chikugo-89 was avirulent to the NILs carrying bph20(t) and Bph21(t) while the BPH strains of Isahaya-99 and Nishigoshi-05 were virulent to the NILs (Tables 1-6). Myint et al. (2009a) reported that the BPH strain of Chikugo-89 was virulent to Mudgo carrying Bph1 but avirulent to ASD7 carrying bph2 while the BPH strains of Isahaya-99 and Nishigoshi-05 were virulent to Mudgo and ASD7. The different patterns of the virulence against Bph1 infested by Chikugo-89 strain suggest that the response of resistance caused by each bph20(t) and Bph21(t) is different from that of Mudgo carrying Bph1, but similar to that of ASD7 carrying bph2. Further genetic analysis is needed to clarify the identification between Bph21(t) and bph2.

Recent molecular mapping suggests that highly resistant varieties of rice carry multiple genes for resistance to BPH (Huang et al., 2001; Sonoda et al., 2003; Sun et al., 2005). Our results also suggested that the PYL with both of the BPH resistance genes, bph20(t) and Bph21(t), mediated a high level of resistance against the BPH strains collected since 1999 in Japan. The pyramiding of multiple resistance genes is obviously an advantageous strategy for increasing the durability of resistance, as it is unlikely that the insect would be able to simultaneously overcome multiple genes for resistance.

\section{ACKNOWLEDGEMENTS}

We thank the staff members of the Research Team for Insect Pest and Nematode Management, the National Agricultural Research Center for Kyushu Okinawa Region for their technical support. This work was partially supported by a Grant-in-Aid for Scientific Research (17580007) from the Ministry of Education, Culture, Sports, Science, and Technology and by a grant (Rice Genome Project, QT-4010) from the Ministry of Agriculture, Forestry and Fisheries of Japan.

\section{REFERENCES}

Diehl, S. R. and G. L. Bush 1984 An evolutionary and applied perspective of insect biotypes. Ann. Rev. Entomol., 29: 471-504

Haung, Z., G. He, L. Shu, X. Li and Q. Zhang 2001 Identification and mapping of two brown planthopper resistance genes in rice. Theor. Appl. Genet., 102: 929-934

Khush, G. S. 1979 Genetics of and breeding for the resistance to the brown planthopper. In "Brown Planthopper: Threat To Rice Production In Asia". International Rice Research Institute, Los Baños, Philippines, pp. 321-332

Ling K. C., E. R. Tiongco and V. M. Aguiero 1978 Rice ragged stunt. A new virus disease. Plant Dis. Rep., 62: 701-705 
Myint, K. K. M., H. Yasui, M. Takagi and M. Matsumura 2009a Virulence of long-term laboratory populations of the brown planthopper, Nilaparvata lugens (Stål), and whitebacked planthopper, Sogatella furcifera (Horváth) (Homoptera: Delphacidae), on rice differential varieties. Appl. Entomol. Zool., 44: 149-153

Myint, K. K. M., M. Matsumura, T. Sonoda, A. Yoshimura and H. Yasui 2009b Mapping of two major genes resistance to the brown planthopper, Nilaparvata lugens (Stål) in a highly resistant rice cultivar ADR52. Theor. Appl. Genet.

Pathak P. K. and E. A. Heinrichs 1982 Selection of biotype populations 2 and 3 of Nilaparvata lugens by exposure to resistant rice varieties. Environ. Entomol., 11: 85-90

Rivera C. T., S. H. Ou and T. T. Iida 1966 Grassy stunt disease of rice and its transmission by the brown planthopper, Nilaparvata lugens Stal. Plant Dis. Rep., 50: 453-456

SAS Institute Inc. 2003 JMP ${ }^{\circledR}$ User's Guide, Version 5.1, SAS Institute Inc., Cary, North Carolina, USA
Sogawa K. 1992 Rice brown planthopper (BPH) immigrants in Japan change biotype. Intl. Rice Res. Newsl., 17(2): 26-27

Sonoda, T., A. Yoshimura and H. Yasui 2003 Detection of QTLs for antibiosis to brown planthopper, Nilaparvata lugens Stål in rice, Oryza sativa L. Rice Genet. Newsl., 20: 85-88

Sun L, C. Su, C. Wang, H. Zhai and J. Wan 2005 Mapping of a major resistance gene to the brown planthopper in the rice cultivar Rathu Heenati. Breed. Sci., 55: 391-396

Tanaka, K. 1999 Recent status in virulence to resistant rice varieties of brown planthopper Nilaparvata lugens immigrating into Japan. Ann. Rep. Kanto Pl. Prot. Soc., 46: 85-88 (in Japanese with English summary)

Tanaka, K. 2000 A simple method for evaluating the virulence of the brown planthopper. Intl. Rice Res. Newsl., 25(1): 18-19

Tanaka K. and M. Matsumura 2000 Development of virulence to resistant rice varieties in the brown planthopper, Nilaparvata lugens (Homoptera: Delphacidae), immigrating into Japan. Appl. Entomol. Zool., 35(4): 529-533 